\author{
ELWIRA MARSZAŁKOWSKA-KRZEŚ \\ ORCID: 0000-0003-3276-4438 \\ Uniwersytet Wrocławski
}

\title{
ZASADY DOKONYWANIA DORĘCZEŃ PO NOWELIZACJI K.P.C. WPROWADZONEJ USTAWA Z 4 LIPCA 2019 ROKU
}

\begin{abstract}
Abstrakt: Przedmiotem opracowania jest istotne dla prawidłowego przebiegu postępowania cywilnego zagadnienie dokonywania doręczeń stronom oraz innym podmiotom uczestniczącym w postępowaniu cywilnym. Prawidłowe dokonanie doręczeń pism procesowych i sądowych ma wpływ na zapewnienie realizacji ochrony prawnoprocesowej. Dokonanie doręczenia pism procesowych i sądowych wiąże się z rozpoczęciem biegu terminów procesowych, ale także ma wpływ na dochowanie terminów materialnoprawnych. W artykule opisane zostały przede wszystkim nowe regulacje w zakresie zasad dokonywania doręczeń wprowadzone na mocy ustawy z 4 lipca 2019 roku o zmianie ustawy Kodeks postępowania cywilnego oraz niektórych innych ustaw (Dz.U. z 2019 r. poz. 1469), podjęto również kwestię doręczeń przez komornika sądowego. Poza zakresem analizy znalazły się natomiast zagadnienia dotyczące doręczeń w europejskim i międzynarodowym postępowaniu cywilnym.
\end{abstract}

Słowa kluczowe: doręczenia, pisma sądowe, postępowanie cywilne

\section{WSTĘP}

Zasada czynnego udziału stron postępowania cywilnego wymaga zagwarantowania także prawidłowych czynności w zakresie dokonywania doręczeń pism procesowych i sądowych. Od prawidłowego dokonania doręczenia tych pism zależy także wiele skutków procesowych.

W odróżnieniu od czynności orzeczniczych, czyli decyzyjnych sądu, doręczenie stanowi czynność pomocniczą, dlatego mimo że jest niewątpliwie czynnością procesową, to ma charakter zabiegów procesowych ${ }^{1}$. Dokonanie prawidłowego doręczenia pism sądowych, chociaż traktowane jest jako czynność o charakterze technicznoprocesowym, to zapewnia realizację ochrony prawnoprocesowej. Nieprawidłowości w zakresie doręczenia mogą doprowadzić do stwierdzenia nie-

1 W. Broniewicz, A. Marciniak, I. Kunicki, Postępowanie cywilne w zarysie, Warszawa 2016, s. 99. 
ważności postępowania, jeśli w ich rezultacie strona nie miała możliwości obrony swych praw ${ }^{2}$. Zagadnienie związane $z$ dokonywaniem doręczeń można wiązać albo z zasadą pisemności, jeśli doręczenia dokonuje strona ${ }^{3}$, bądź z zasadą oficjalności w przypadku dokonywania doręczeń przez sąd. Doręczenie pisma stronie w procesie, a odpowiednio uczestnikowi postępowania w postępowaniu nieprocesowym, stanowi jeden z elementów umożliwiających skorzystanie z instrumentów prawnych w ramach ochrony prawnoprocesowej. Ponadto prawidłowe doręczenie wiąże się z rozpoczęciem biegu terminów procesowych dla dokonania określonej czynności przez stronę lub uczestnika postępowania nieprocesowego oraz innych podmiotów ${ }^{4}$ uczestniczących w postępowaniu cywilnym, ale także ma wpływ na dochowanie terminów materialnoprawnych (jak w przypadku powództwa eksydencyjnego, które można wytoczyć w terminie miesiąca od dnia dowiedzenia się o naruszeniu prawa; por. art. $847 \S 2$ KPC).

Przedmiotem analizy będą przede wszystkim nowe regulacje w zakresie dokonywania doręczeń prowadzone na mocy ustawy z 4 lipca 2019 roku $^{5}$, dlatego poza zakresem analizy znalazły się zagadnienia dotyczące doręczeń w europejskim i międzynarodowym postępowaniu cywilnym ${ }^{6}$.

\section{ZASADY DOKONYWANIA DORĘCZEŃ}

Kodeks postępowania cywilnego nie wprowadza odrębnej definicji „doręczenia", lecz określa jedynie zasady dokonywania doręczeń. Pojęcie to zostało zdefiniowane w art. 3 pkt 4) ustawy z dnia listopada 2012 roku Prawo Pocztowe 7 , zgodnie z którym przez „doręczenie” rozumie się wydanie przesyłki pocztowej adresatowi, a w przypadkach określonych prawem także innej osobie, lub przekazanie druku bezadresowego zgodnie z umową o świadczenie usługi pocztowej. Jak zasadnie dostrzega się w literaturze, z przedmiotowej definicji można czerpać tylko częściowo, ponieważ w przypadku skorzystania przez sąd z doręczenia za

2 T. Wiśniewski, Przebieg procesu cywilnego, Warszawa 2013.

3 A. Góra-Błaszczykowska, Zasada równości w postępowaniu cywilnym, Warszawa 2008, s. 309.

${ }^{4}$ Doręczeń dokonuje się także ustawowym przedstawicielom stron lub uczestnikom postępowania nieprocesowego, ich pełnomocnikom, ale również podmiotom działającym na prawach strony, interwenientowi ubocznemu, świadkom, biegłym, tłumaczom i innym.

5 Ustawa z 4 lipca 2019 roku o zmianie ustawy Kodeks postępowania cywilnego oraz niektórych innych ustaw (Dz.U. z 2019 r. poz. 1469).

${ }^{6}$ W tym zakresie por. Rozporządzenie Nr 1393/2007 Parlamentu Europejskiego i Rady z 13 listopada 2007 roku dotyczące doręczania w państwach członkowskich dokumentów sądowych i pozasądowych w sprawach cywilnych i handlowych oraz uchylające rozporządzenie Rady (WE) Nr 1348/2000 (Dz.Urz. UE L Nr 324, s. 79 ze zm.).

${ }^{7}$ Ustawy z dnia 23 listopada 2012 roku — Prawo Pocztowe (tekst jedn. Dz.U. z 2020 r. poz. 2320). 
pośrednictwem innych uprawnionych podmiotów niż operator pocztowy (to jest doręczeniowej służby sądowej, pracownika sądu, komornika sądowego), to wówczas ,przesyłka sądowa” nie ma charakteru przesyłki pocztowej ${ }^{8}$.

Czynności związane $\mathrm{z}$ dokonywaniem doręczeń uregulowano $\mathrm{w}$ przepisach Kodeksu postępowania cywilnego (w dziale I zatytułowanym „Przepisy ogólne o czynnościach procesowych" i w rozdziale 2 - „Doręczenia”).

Zgodnie z zasadą oficjalności doręczeń, jeżeli obowiązek dokonania doręczenia spoczywa na organie, to dokonuje on doręczenia z urzędu (por. art. $357 \S 2$ k.p.c., zgodnie z którym postanowienie wydane na posiedzeniu niejawnym sąd doręcza stronom z urzędu, chyba że przepis szczególny stanowi inaczej).

$\mathrm{W}$ celu usprawnienia przebiegu postępowania wprowadzono zasadę osobistego dokonywania doręczeń, która polega na dokonywaniu doręczeń pism procesowych samodzielnie w przypadku profesjonalnych pełnomocników, rzecznika patentowego oraz Prokuratorii Generalnej RP (por. art. $132 \S 1$ k.p.c.). W treści pisma procesowego wnoszonego do sądu zamieszcza się oświadczenie o doręczeniu odpisu pisma drugiej stronie albo o jego nadaniu przesyłką poleconą. Zaniechanie zamieszczenia takiego oświadczenia spowoduje zwrot pisma bez wzywania do usunięcia tego braku. Powyższa forma dokonywania doręczeń nie ma zastosowania w przypadku powództwa wzajemnego, apelacji, skargi kasacyjnej, zażalenia, sprzeciwu od wyroku zaocznego, sprzeciwu od nakazu zapłaty, zarzutów od nakazu zapłaty, wniosku o zabezpieczenie powództwa, skargi o wznowienie postępowania, skargi o stwierdzenie niezgodności z prawem prawomocnego orzeczenia i skargi na orzeczenia referendarza sądowego.

Wyróżnia się zasadę doręczeń bezpośredniego (właściwego) oraz pośredniego (zastępczego). Doręczenie właściwe polega na dokonaniu doręczenia pisma bezpośrednio adresatowi, a do zastępczych zalicza się doręczenie podmiotom innym niż adresat (art. 138 k.p.c.), a także doręczenie w inny sposób niż przez oddanie pisma określonemu podmiotowi niebędącemu jego adresatem poprzez awizo (art. 139 k.p.c.) czy też pozostawienie w aktach sprawy ${ }^{9}$. W przypadku ustanowienia pełnomocnika lub osoby upoważnionej do odbioru pism sądowych doręczenia należy dokonać tym osobom. Skarbowi Państwa doręczenia dokonuje się poprzez organ uprawniony do reprezentowania przed sądem lub do rąk pracownika upoważnionego do odbioru pism.

Mimo zmian przepisów k.p.c. w zakresie dokonywana doręczeń, utrzymano regułę, że „W razie ustanowienia pełnomocnika procesowego lub osoby upoważnionej do odbioru pism sądowych, to pisma sądowe doręcza się tym osobom". Natomiast dodano, że pismo wzywające stronę do osobistego stawiennictwa należy doręczyć tylko bezpośrednio tej stronie, z wyjątkiem strony, o której mowa

${ }^{8}$ M. Michalska-Marciniak, rozdział 2, pkt 3, [w:] Kodeks postępowania cywilnego, t. 1. Komentarz do art. 1-205, red. A. Marciniak, Warszawa 2019.

${ }^{9}$ K. Kołakowski, [w:] Kodeks postepowania cywilnego, t. 1. Komentarz do art. 1-399, red. K. Piasecki, Warszawa 2010, s. 701. 
w art. $1135^{5} \S 1$, a więc nieposiadającej miejsca zamieszkania lub zwykłego pobytu albo siedziby w Rzeczypospolitej Polskiej lub w innym państwie członkowskim Unii Europejskiej. W takim bowiem przypadku osoba taka, o ile nie ustanowiła pełnomocnika do prowadzenia sprawy zamieszkałego w RP, ,jest obowiązana wskazać pełnomocnika do doręczeń w RP"10.

Sąd powinien w przypadku doręczenia zastępczego zweryfikować, w jaki sposób adresat został zawiadomiony o nadejściu przesyłki oraz gdzie i w jakim terminie może ją odebrać na podstawie zwrotnego potwierdzenia odbioru, z którego powinno wynikać czy dopełniono wszystkich warunków pozwalających na stwierdzenie skuteczności doręczenia. Innymi słowy, musi istnieć pewność co do tego, że nastąpiło prawidłowe zawiadomienie. Adresat musi być zawiadomiony zarówno o pozostawieniu pisma, jak i miejscu, gdzie może je odebrać oraz o terminie odbioru, a zwrotne potwierdzenie odbioru powinno być wypełnione czytelnie wraz z podpisem listonosza ${ }^{11}$. Ponadto skorzystanie z prawnego domniemania doręczenia zastępczego wymaga dopełnienia ściśle określonych czynności przez podmiot doręczający, w tym wymogu dwukrotnej awizacji przesyłki ${ }^{12}$. Jak zasadnie dostrzega się $\mathrm{w}$ orzecznictwie, instytucja doręczenia zastępczego stanowi rozwiązanie wyjątkowe i jako taka powinna być stosowana przy ścisłym przestrzeganiu zasad i procedur, a dla skutecznego powołania się na domniemanie doręczenia zastępczego konieczne jest spełnienie wszystkich elementów tej procedury, dlatego tak ważne znaczenie ma zwrotne potwierdzenie odbioru, które musi zawierać pełną informację o sposobie poinformowania adresata o pozostawieniu pisma oraz o miejscu i terminie jego odbioru, a także być czytelnie wypełnione i podpisane przez doręczyciela ${ }^{13}$.

W wyniku zmian k.p.c. zmodyfikowany został także przepis art. $133 \S 2^{1}$ k.p.c., w myśl którego pisma procesowe lub orzeczenia dla przedsiębiorcy wpisanego do Centralnej Ewidencji i Informacji o Działalności Gospodarczej doręcza się na adres do doręczeń udostępniony w tej ewidencji, chyba że przedsiębiorca wskazał inny. Z kolei pisma procesowe lub orzeczenia dla przedsiębiorcy wpisanego do rejestru sądowego doręcza się na adres udostępniony w tym rejestrze, chyba że przedsiębiorca wskazał inny. Jeżeli ostatni udostępniony adres został wykreślony jako niezgodny z rzeczywistym stanem rzeczy i nie zgłoszono wniosku o wpisanie nowego, który podlegałby udostępnieniu, adres wykreślony jest uważany za adres udostępniony w rejestrze (art. $133 \S 2^{2}$ k.p.c.). W przypadku kiedy stronie podlegającej wpisowi do rejestru sądowego nie można doręczyć pisma we wspomniany sposób ze względu na nieujawnienie w tym rejestrze zmiany

${ }^{10}$ I. Gil, Nowelizacja Kodeksu postępowania cywilnego - zmiany wprowadzone ustawa z 4.7.2019 r. oraz innymi ustawami - tabela porównawcza z komentarzem, „Monitor Prawniczy” 2020 , nr 6 .

11 Wyrok NSA z 17sierpnia 2011 roku, II GSK 794/10.

12 Wyrok WSA w Warszawie z 17 września 2020 roku, VI SA/Wa 1358/20.

13 Wyrok NSA z 7 maja 2020 roku, I OSK 920/19. 
adresu, pismo to pozostawia się w aktach sprawy ze skutkiem doręczenia, chyba że nowy adres jest sądowi znany (art. 139 § 3 k.p.c.).

Wprowadzony został także obowiązek stwierdzenia w wydawanym zaświadczeniu faktu uchylenia zarządzenia o uznaniu wyroku lub nakazu za skutecznie doręczony, bo stosownie do przepisu art. $139 \S 5$ k.p.c. na wniosek strony wydaje się zaświadczenie, że wyrok zaoczny albo nakaz zapłaty został uznany za doręczony na oznaczony adres w sposób przewidziany w $\S 1$. W zaświadczeniu takim stwierdza się $\mathrm{z}$ urzędu fakt uchylenia zarządzenia o uznaniu wyroku albo nakazu za doręczony.

Natomiast doręczenie za pośrednictwem systemu teleinformatycznego uważane jest za doręczenie właściwe, gdyż dociera do adresata, ale z wykorzystaniem systemu informatycznego ${ }^{14}$. Powyższa forma dokonania doręczenia pisma może mieć miejsce jedynie w przypadku, gdy adresat wniósł pismo za pośrednictwem systemu teleinformatycznego. $Z$ tej formy dokonywania doręczeń adresat zawsze może zrezygnować. W przypadku doręczenia $\mathrm{z}$ wykorzystaniem formy elektronicznej pismo uznaje się za doręczone w chwili wskazanej w elektronicznym potwierdzeniu odbioru korespondencji. W razie braku takiego potwierdzenia skuteczność dokonanego doręczenia uznaje się po upływie czternastu dni od daty umieszczenia pisma w systemie teleinformatycznym. Przepis art. $131 \S 1$ k.p.c. nie dotyczy pism wnoszonych za pośrednictwem systemu teleinformatycznego, podlegających doręczeniu adwokatowi, radcy prawnemu, rzecznikowi patentowemu lub Prokuratorii Generalnej Rzeczypospolitej Polskiej, którzy dokonali wyboru wnoszenia pism za pośrednictwem systemu teleinformatycznego i nie zrezygnowali z doręczenia elektronicznego (art. $131 \S 1^{2}$ k.p.c.).

Adwokat, radca prawny, rzecznik patentowy oraz Prokuratoria Generalna Rzeczypospolitej Polskiej doręczają sobie nawzajem pisma procesowe z załącznikami bezpośrednio wyłącznie w postaci elektronicznej, jeżeli złożą sądowi zgodne oświadczenia odpowiedniej treści i podadzą do wiadomości sądu użyte w tym celu dane kontaktowe, zwłaszcza adres poczty elektronicznej lub numer faksu. Oświadczenia nie podlegają odwołaniu, a zastrzeżenia warunku lub terminu uważa się za nieistniejące. Na zgodny wniosek stron lub w innych uzasadnionych przypadkach sąd zarządza odstąpienie od takiego sposobu doręczania (art. $131 \S 1^{3}$ k.p.c.).

\section{PRZEDMIOT DORĘCZENIA}

Ze względu na różnorodność czynności procesowych oraz rodzajów pism, które wymagają doręczenia, określenie, co stanowi przedmiot doręczenia, może

14 M. Michalska-Marciniak, Wadliwość doręczenia w trybie art. 139 § 1 k.p.c. a wniosek o przywrócenie terminu do wniesienia środka zaskarżenia, „Polski Proces Cywilny” 2011, $\mathrm{nr} 3$, s. 136. 
budzić wątpliwości. $Z$ treści przepisów k.p.c. o doręczeniach można wysnuć wniosek, że przedmiotem tych ostatnich będą zarówno „pisma sądowe” (por. art. 131 $\S 2$, art. $133 \S 3$, art. $135 \S 2$ k.p.c.), jak też „pismo” (art. $131^{1} \S 2$, art. $132 \S 1$ zd. 3 i 2 k.p.c.) czy też pismo procesowe (art. $132 \S 1$, art.133 § 2 i 2a, art. 140 KPC), a także orzeczenie (art. $133 \S 2$, art. 140 k.p.c.). Powyższa regulacja powoduje, że w kwestii przedmiotu doręczenia wykształciły się dwa poglądy. Pierwszy, według którego przedmiotem doręczeń są pisma sądowe obejmujące pisma procesowe kierowane przez uczestników postępowania do organów procesowych i egzekucyjnych (obejmujące wnioski i oświadczenia tych podmiotów) oraz pisma organów procesowych i egzekucyjnych ( $w$ tym orzeczenia formalne i merytoryczne, zawiadomienia) ${ }^{15}$. Natomiast przedstawiciele drugiego stanowiska dokonują podziału przedmiotu doręczeń na pisma sądowe i pisma procesowe ${ }^{16}$. W ramach niniejszego opracowania przedmiotem omówienia będą czynności podejmowane w związku dokonywaniem doręczeń przez sąd z uwzględnieniem wprowadzonych zmian przepisów k.p.c. na mocy wspomnianej nowelizacji ustawą z 4 lipca 2019 roku.

\section{DOKONYWANIE DORĘCZEŃ PISM SĄDOWYCH}

W wyniku nowelizacji k.p.c. wprowadzonej ustawą z dnia 4 lipca 2019 roku zmianie uległ przepis art. $131 \S 1$ k.p.c., stosownie do którego sąd dokonuje doręczeń przez operatora pocztowego w rozumieniu ustawy Prawo pocztowe, osoby zatrudnione w sądzie lub sądową służbę doręczeniową, ale może też dokonywać doręczeń za pośrednictwem komornika w sposób określony w ustawie z dnia 22 marca 2018 roku o komornikach sądowych. W uzasadnieniu do projektu przedmiotowej ustawy nowelizującej stwierdzono, że

jednym z największych problemów w praktyce funkcjonowania sądów cywilnych jest doręczenie pierwszego pisma w sprawie (odpisu pozwu/wniosku z załącznikami oraz, w obecnym stanie prawnym, z zawiadomieniem o rozprawie). Znaczenie doręczenia pierwszego pisma w sprawie jest kluczowe dla całego dalszego postępowania, ponieważ z założenia powoduje uznanie za doręczone wszystkich kolejnych pism sądowych - łącznie z tymi, które wywołują potrzebę obrony swych praw przez stronę. $Z$ reguły jedyną podstawą oceny, czy pismo należy uznać za doręczone, jest adnotacja na dowodzie doręczenia.

Zdaniem autorów projektu sprawność czynności związanych z dokonywaniem doręczeń wzrośnie przy wykorzystaniu doręczeń z udziałem komorników

15 W. Broniewicz, A. Marciniak, I. Kunicki, Postępowanie cywilne w zarysie, Warszawa 2016, s. 109; H. Pietrzkowski, Metodyka pracy sędziego w sprawach cywilnych, Warszawa 2012, s. 277; E. Stefańska, [w:] Kodeks postępowania cywilnego. Komentarz, red. M. Manowska, Warszawa 2013 s. 253.

16 Z. Resich, [w:] J. Jodłowski et al., Postępowanie cywilne, s. 330 n.; W. Broniewicz, A. Marciniak, I. Kunicki, op. cit., s. 99; E. Marszałkowska-Krześ, [w:] Postępowanie cywilne, red. E. Marszałkowska-Krześ, Warszawa 2013, s. 256. 
sądowych, którzy dysponują większymi możliwościami w zakresie uzyskania informacji odnośnie faktycznego miejsca pobytu adresata niż operatorzy pocztowi dokonujący tradycyjnych doręczeń.

Sąd dokonuje doręczeń przez:

- operatora pocztowego w rozumieniu ustawy z dnia 23 listopada 2012 roku - Prawo pocztowe ${ }^{17}$,

- osoby zatrudnione w sądzie lub

- sądową służbę doręczeniową,

— komornika w sposób określony w ustawie z dnia 22 marca 2018 roku o komornikach sądowych ${ }^{18}$ (por. art. $131 \S 1$ k.p.c.),

— przez Policję lub Żandarmerię Wojskową w wypadkach wskazanych w ustawie (art. $\S 1^{1}$ k.p.c.).

Szczegółowy tryb i sposób doręczania pism sądowych przez operatora pocztowego Minister Sprawiedliwości określił w porozumieniu z ministrem właściwym do spraw łączności (art. $131 \S 2$ k.p.c.).

Natomiast służbę doręczeniową na uzasadniony wniosek prezesa sądu, w drodze zarządzenia, tworzy i znosi w tym sądzie § 3. Minister Sprawiedliwości określa także w drodze rozporządzenia warunki organizacji oraz strukturę sądowej służby doręczeniowej, mając na względzie wielkość sądu, koszty oraz zapewnienie skuteczności doręczeń i zachowanie wymogów postępowania sądowego.

\section{DOKONYWANIE DORĘCZEŃ PRZEZ KOMORNIKA SĄDOWEGO}

Przepis art. 131 k.p.c. pozostaje w związku z przepisem dodanym art. 1391 k.p.c. oraz przepisem art. 3a, również dodanym w ustawie o komornikach sądowych. Zgodnie z przepisem art. $139^{1}$ k.p.c. $\$ 1$ k.p.c. — jeżeli pozwany, pomimo powtórzenia zawiadomienia zgodnie $\mathrm{z}$ art. $139 \S 1 \mathrm{zd}$. 2, nie odebrał pozwu lub innego pisma procesowego wywołującego potrzebę podjęcia obrony jego praw, a w sprawie nie doręczono mu wcześniej żadnego pisma w sposób przewidziany $\mathrm{w}$ artykułach poprzedzających i nie ma zastosowania art. $139 \S 2-3^{1}$ lub inny przepis szczególny przewidujący skutek doręczenia, przewodniczący zawiadamia o tym powoda, przesyłając mu przy tym odpis pisma dla pozwanego i zobowiązując do doręczenia tego pisma pozwanemu za pośrednictwem komornika.

Warunkiem wydania przez przewodniczącego zarządzenia zobowiązującego powoda do doręczenia pisma pozwanemu za pośrednictwem komornika jest uprzednie podjęcie czynności doręczenia w sposób przewidziany w przepisie art. 139 k.p.c. A zatem należy wyczerpać następujący tryb:

17 Ustawa z dnia 23 listopada 2012 roku - Prawo pocztowe (Dz.U. z 2020 r. poz. 1041).

18 Ustawa z dnia 22 marca 2018 roku o komornikach sądowych (Dz.U. z 2020 r. poz. 121 i 288). 
1) w razie niemożności doręczenia w sposób przewidziany w przepisach wcześniejszych, to jest w art. 133-138 k.p.c., pismo przesłane za pośrednictwem operatora pocztowego w rozumieniu ustawy Prawo pocztowe należy złożyć w placówce pocztowej tego operatora, a doręczane w inny sposób - w urzędzie właściwej gminy, umieszczając zawiadomienie o tym w drzwiach mieszkania adresata lub w oddawczej skrzynce pocztowej ze wskazaniem, gdzie i kiedy pismo pozostawiono, oraz z pouczeniem, że należy je odebrać w terminie siedmiu dni od dnia umieszczenia zawiadomienia;

2) w przypadku bezskutecznego upływu siedmiodniowego terminu czynność zawiadomienia należy powtórzyć.

W odniesieniu do podmiotu podlegającego wpisowi do rejestru sądowego nie będzie miała zastosowania regulacja przewidziana $\mathrm{w}$ art. $139^{1}$ k.p.c., albowiem w stosunku do takich podmiotów, jeżeli nie można doręczyć im pisma ze względu na nieujawnienie w tym rejestrze zmiany adresu, pismo to pozostawia się w aktach sprawy ze skutkiem doręczenia, chyba że nowy adres jest sądowi znany. Podobnie pisma kierowane do osób reprezentujących podmiot wpisany do Krajowego Rejestru Sądowego, likwidatorów, prokurentów, członków organów lub osób uprawnionych do powołania zarządu - w razie niemożności doręczenia z uwagi na niezgłoszenie oświadczenia o zmianie adresu do doręczeń, pozostawia się je w aktach sprawy ze skutkiem doręczenia, chyba że inny adres do doręczeń lub miejsce zamieszkania i adres są sądowi znane (art. $139 \S 3^{1}$ k.p.c.). Sąd rejestrowy przy ogłoszeniu lub doręczeniu postanowienia o pierwszym wpisie poucza wnioskodawcę o skutkach zaniedbania ujawnienia w rejestrze zmian dotyczących adresu dla doręczeń (art. 139 § 4 k.p.c.). Pouczenie podmiotu wpisanego do Krajowego Rejestru Sądowego jest jednoznaczne z pouczeniem osób, o których mowa w zdaniu pierwszym (art. 139 § 4 k.p.c.).

Kolejną podstawą warunkującą możliwość dokonania doręczenia za pośrednictwem komornika sądowego jest zaniechanie odebrania przez pozwanego pozwu lub innego pisma procesowego wywołującego potrzebę podjęcia obrony jego praw, jeżeli dotychczas w sprawie nie doręczono mu wcześniej żadnego pisma w sposób przewidziany w artykułach poprzedzających i nie ma zastosowania art. $139 \S 2-3^{1}$ lub inny przepis szczególny przewidujący skutek doręczenia.

Przewodniczący zawiadamia wówczas powoda o spełnieniu powyższych warunków, jednocześnie przesyłając mu przy tym odpis pisma dla pozwanego i zobowiązując do doręczenia tego pisma pozwanemu za pośrednictwem komornika. Korespondencja, która miałaby zostać doręczona przez komornika, powinna być zabezpieczona przez sąd w taki sposób, żeby można ją było przekazać komornikowi do doręczenia.

Ani przepisy k.p.c., ani regulacje ustawy o komornikach sądowych nie regulują kwestii właściwości komornika, który miałby dokonać takiego doręczenia. Doręczanie korespondencji przez komornika sądowego z pewnością nie jest 
czynnością, jaką podejmuje komornik jako organ egzekucyjny w postępowaniu zabezpieczającym lub w postępowaniu egzekucyjnym.

Stosownie do przepisu art. 3 ust. 3 u.k. komornikom powierza się następujące zadania:

1) wykonywanie orzeczeń sądowych w sprawach o roszczenia pieniężne i niepieniężne oraz zabezpieczenie roszczeń, w tym europejskich nakazów zabezpieczenia na rachunku bankowym, z uwzględnieniem wyjątków przewidzianych w przepisach k.p.c.;

2) wykonywanie innych tytułów wykonawczych oraz tytułów egzekucyjnych, które podlegają wykonaniu w drodze egzekucji sądowej bez zaopatrywania ich w klauzulę wykonalności;

2a) wykonywanie postanowień o zabezpieczeniu środka dowodowego oraz postanowień nakazujących wydanie środka dowodowego w postępowaniu w sprawach własności intelektualnej;

3) wykonywanie postanowień o zabezpieczeniu spadku lub sporządzanie spisu inwentarza;

4) wykonywanie zadań określonych w innych ustawach.

Czynności związane $\mathrm{z}$ dokonaniem doręczenia nie mieszczą się w powyższym katalogu, z przepisu art. 3 ust. 4 u.k.s. wynika bowiem, że komornik, poza zadaniami określonymi w ust. 3 , wykonuje następujące czynności:

1) na zlecenie sądu albo wniosek powoda zobowiązanego przez sąd na podstawie art. $1391 \S 1$ k.p.c. osobiście doręcza bezpośrednio adresatowi zawiadomienia sądowe, pisma procesowe oraz inne dokumenty sądowe za potwierdzeniem odbioru i oznaczeniem daty, albo stwierdza, że adresat pod podanym adresem nie zamieszkuje;

1a) na zlecenie podmiotu, o którym mowa w pkt 1 , podejmuje czynności zmierzające do ustalenia aktualnego adresu zamieszkania adresata;

2) sporządza protokół stanu faktycznego;

3) na wniosek organizatora licytacji sprawuje urzędowy nadzór nad dobrowolnymi publicznymi licytacjami, z przybiciem najniższej lub najwyższej oferty.

Ponadto na mocy regulacji zawartej w przepisie art. 3 ust. 5 u.k.s. na czynności komornika, o których mowa w ust. 4 pkt 1 i 2, przysługuje skarga do sądu rejonowego. Przepisy k.p.c., a w szczególności art. 759 § 2 i art. 767-7674, stosuje się odpowiednio. Zażalenie na postanowienie sądu nie przysługuje $\mathrm{z}$ wyjątkiem postanowień w przedmiocie kosztów komorniczych. Dokonując wykładni literalnej przedmiotowej regulacji, należy uznać, że skoro odpowiednie stosowanie przepisów k.p.c. ma miejsce wyłącznie w zakresie zaskarżania czynności związanych z dokonaniem doręczeń na zarządzenie sądu lub w zakresie sporządzania protokołu stanu faktycznego, to w odniesieniu do pozostałych czynności określonych w art. 3 ust. 4 pkt. 1a) oraz art. 3 ust. 4 pkt. 3 u.k.s. przepisy k.p.c. w ogóle nie będą miały zastosowania. 
Wszystkie czynności określone w przepisie art. 3 ust. 4 u.k.s. podejmowane są przez komorników sądowych w ramach innych zadań niż powierzone, na podstawie art. 3 ust. 3, związanych z pełnieniem funkcji organu egzekucyjnego.

W związku z powyższym nie będą miały zastosowania do tego rodzaju czynności przepisy o właściwości miejscowej komornika sądowego uregulowane w przepisach k.p.c., a w konsekwencji nie będą także miały zastosowania ograniczenia przewidziane w przepisie art. 10 u.k.s. w zakresie korzystania z wyboru właściwości komornika poza rewirem. Przedmiotowa regulacja odnosi się bowiem do czynności komorników sądowych podejmowanych w postępowaniu zabezpieczającym i egzekucyjnym.

\section{ZAKOŃCZENIE}

Reasumując, powód może wystąpić do dowolnego komornika sądowego z wnioskiem o dokonanie osobistego doręczenia bezpośrednio adresatowi zawiadomienia sądowego, pisma procesowego, jak też innych dokumentów sądowych za potwierdzeniem odbioru i oznaczeniem daty, albo stwierdzenia, że adresat pod podanym adresem nie zamieszkuje.

W myśl art. $139^{1} \S 2$ k.p.c powód w terminie dwóch miesięcy od dnia doręczenia mu zobowiązania, o którym mowa w $\S 1$, składa do akt potwierdzenie doręczenia pisma pozwanemu za pośrednictwem komornika albo zwraca pismo i wskazuje aktualny adres pozwanego lub dowód, że pozwany przebywa pod adresem wskazanym w pozwie. Po bezskutecznym upływie terminu stosuje się przepis art. $177 \S 1$ pkt 6 k.p.c.

Przedmiotowa regulacja ma uchronić stronę pozwaną przed naruszeniem jej praw do obrony, umożliwia jednak powodowi uwzględnienie w tym samym czasie wniosku o ustanowienie kuratora dla doręczeń. Zgodnie z przepisem art. 143 k.p.c. jeżeli stronie, której miejsce pobytu nie jest znane, ma być doręczony pozew lub inne pismo procesowe wywołujące potrzebę podjęcia obrony jej praw, to doręczenie może do chwili zgłoszenia się strony albo jej przedstawiciela lub pełnomocnika nastąpić tylko do rąk kuratora ustanowionego na wniosek osoby zainteresowanej przez sąd orzekający. Niezbędnym warunkiem ustanowienia kuratora przez przewodniczącego jest uprawdopodobnienie przez wnioskodawcę, że miejsce pobytu strony nie jest znane. W sprawach o roszczenia alimentacyjne, jak również w sprawach o ustalenie pochodzenia dziecka i o związane z tym roszczenia, przewodniczący przed ustanowieniem kuratora przeprowadza stosowne dochodzenie w celu ustalenia miejsca zamieszkania lub pobytu pozwanego (art. $144 \S 1$ k.p.c.).

W orzecznictwie podkreśla się, że: 1. zgodnie z ogólną regułą wynikającą z art. 6 k.c. na składającym oświadczenie woli spoczywa ciężar dowodu, że jego 
oświadczenie doszło do adresata w taki sposób, że mógł się z nim zapoznać w normalnym toku czynności. W przypadku składania oświadczeń woli na odległość za pośrednictwem operatora pocztowego dla oceny, czy adresat mógł zapoznać się ze złożonym oświadczeniem woli, niezbędna jest analiza okoliczności tego doręczenia; 2. bezskuteczne pozostaje, w stosunku do drugiej strony stosunku prawnego, złożenie oświadczenia woli wywołującego skutki materialnoprawne w sytuacji, w której oświadczenie to zostanie złożone wobec kuratora ustanowionego dla tej strony w trybie przepisu art. 144 k.p.c. ${ }^{19}$

Doręczenie staje się skuteczne z chwilą doręczenia pisma kuratorowi (art. 144 $\S 3$ k.p.c.). Sąd może jednak uzależnić skuteczność doręczenia od upływu oznaczonego terminu, który liczy się od chwili wywieszenia obwieszczenia w budynku sądowym.

W praktyce zbyt pochopnie przyjmowana była fikcja dokonania doręczenia, a instytucja przywrócenia terminu nie zawsze mogła ochronić pozwanego przed negatywnymi skutkami domniemania doręczenia. Powyższa regulacja w pewien sposób przerzuca obowiązki na powoda, ale to on właśnie powinien być najbardziej zainteresowany dokonaniem skutecznego doręczenia. Doręczenie przesyłki — pism sądowych i procesowych — umożliwia bowiem stronie zapoznanie się $z$ treścią żądań powoda i podjęcie obrony procesowej. $Z$ tego powodu ustawodawca przewidział regulację, aby podjąć działania umożliwiające doręczenie. Sąd może zrezygnować z dokonania doręczenia, jeżeli byłoby to niecelowe; na przykład na podstawie art. $556 \S 1$ k.p.c. może nie doręczać pism osobie, której dotyczy wniosek o ubezwłasnowolnienie, jeżeli wynika to z opinii lekarza psychiatry lub neurologa bądź psychologa ${ }^{20}$.

Jak zasadnie zostało dostrzeżone w literaturze,

komentowany przepis odnosi się wyłącznie do pism procesowych, a więc pochodzących od stron. Tymczasem zdarza się, że pierwsze doręczenie w sprawie dotyczy postanowienia o przekazaniu sprawy według właściwości innemu sądowi. Następuje ono przed doręczeniem pozwanemu (uczestnikowi postępowania) odpisu pozwu (wniosku). Jednocześnie doręczenie to może się wiązać z potrzebą podjęcia obrony przez pozwanego (uczestnika postępowania), gdy postanowienie jest zaskarżalne zażaleniem. Ustawodawca nie przewidział wówczas możliwości doręczenia odpisu postanowienia przez komornika ${ }^{21}$.

19 Wyrok Sądu Apelacyjnego w Warszawie - V Wydział Cywilny z dnia 4 grudnia 2018 roku, V ACa 1551/17, Legalis nr 1865627.

20 E. Marszałkowska-Krześ, op. cit., s. 278.

21 K. Markiewicz, [w:] Kodeks postepowania cywilnego. Komentarz. Art. 1-50539, red. T. Szanciło, t. 1, Warszawa 2019. 


\section{RULES OF DELIVERY AFTER THE AMENDMENT K.P.C. INTRODUCED BY THE ACT OF JULY 4, 2019}

Summary

The subject of the study is the service of documents to parties and other entities participating in civil proceedings, which is crucial for the proper course of civil proceedings. Correct delivery of pleadings and court documents has an impact on ensuring the implementation of legal and procedural protection. Service of pleadings and court documents is related to the commencement of procedural deadlines, but it also influences the observance of substantive legal deadlines. The article describes the new regulations on the rules of service conducted under the Act of 4 July 2019 on amendments to the Civil Procedure Code and certain other acts (Journal of Laws of 2019, item 1469). However, issues related to service in European and international civil proceedings will be beyond the scope of the analysis. The study also raises the issue of service by bailiff.

Keywords: service, documents, civil proceedings, service by bailiff

\section{BIBLIOGRAFIA}

Broniewicz W., Marciniak A., Kunicki I., Postępowanie cywilne w zarysie, Warszawa 2016.

Gil I., Nowelizacja Kodeksu postępowania cywilnego — zmiany wprowadzone ustawa z 4.7.2019 r. oraz innymi ustawami - tabela porównawcza z komentarzem, „Monitor Prawniczy” 2020, nr 6.

Góra-Błaszczykowska A., Zasada równości w postępowaniu cywilnym, Warszawa 2008.

Kołakowski K., [w:] Kodeks postepowania cywilnego, t. 1. Komentarz do art. 1-399, red. K. Piasecki, Warszawa 2010.

Markiewicz K., [w:] Kodeks postepowania cywilnego. Komentarz. Art. 1-50539, red. T. Szanciło, t. 1, Warszawa 2019.

Marszałkowska-Krześ E., [w:] Postępowanie cywilne, red. E. Marszałkowska-Krześ, Warszawa 2013.

Michalska-Marciniak M., rozdział 2, pkt. 3, [w:] Kodeks postępowania cywilnego, t. 1. Komentarz do art. 1-205, red. A. Marciniak, Warszawa 2019.

Michalska-Marciniak M., Wadliwość doręczenia w trybie art. 139 \$ 1 k.p.c. a wniosek o przywrócenie terminu do wniesienia środka zaskarżenia, „Polski Proces Cywilny” 2011, nr 3.

Pietrzkowski H., Metodyka pracy sędziego w sprawach cywilnych, Warszawa 2012

Resich Z., [w:] Jodłowski J., Resich Z., Lapierre J., Misiuk-Jodłowska T., Weitz K., Postępowanie cywilne, Warszawa 2016.

Stefańska E., [w:] Kodeks postępowania cywilnego. Komentarz, red. M. Manowska, Warszawa 2013.

Wiśniewski T., Przebieg procesu cywilnego, Warszawa 2013.

\section{AKTY PRAWNE}

Rozporządzenie Nr 1393/2007 Parlamentu Europejskiego i Rady z 13 listopada 2007 roku dotyczące doręczania w państwach członkowskich dokumentów sądowych i pozasądowych w sprawach cywilnych i handlowych oraz uchylające rozporządzenie Rady (WE) Nr 1348/2000 (Dz.Urz. UE L nr 324, s. 79 ze zm.).

Ustawa z dnia 23 listopada 2012 roku - Prawo pocztowe (Dz.U. z 2020 r. poz. 1041),

Ustawa z dnia 22 marca 2018 roku o komornikach sądowych (Dz.U. z 2020 r. poz. 121 i 288).

Ustawa z 4 lipca 2019 roku o zmianie ustawy Kodeks postępowania cywilnego oraz niektórych innych ustaw (Dz.U. z 2019 r. poz. 1469). 